
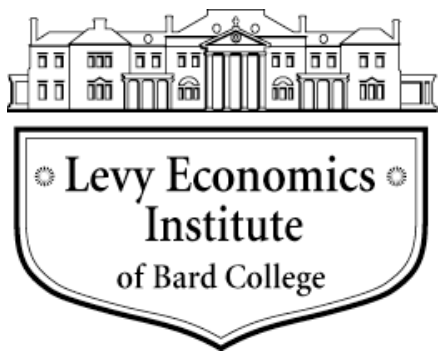

Working Paper No. 738

\title{
At the Crossroads: The Euro and Its Central Bank Guardian (and Savior?)
}

by

\author{
Jörg Bibow \\ Levy Economics Institute of Bard College
}

November 2012

The Levy Economics Institute Working Paper Collection presents research in progress by Levy Institute scholars and conference participants. The purpose of the series is to disseminate ideas to and elicit comments from academics and professionals.

Levy Economics Institute of Bard College, founded in 1986, is a nonprofit, nonpartisan, independently funded research organization devoted to public service. Through scholarship and economic research it generates viable, effective public policy responses to important economic problems that profoundly affect the quality of life in the United States and abroad.

\author{
Levy Economics Institute \\ P.O. Box 5000 \\ Annandale-on-Hudson, NY 12504-5000 \\ http://www.levyinstitute.org
}

Copyright (C) Levy Economics Institute 2012 All rights reserved 


\begin{abstract}
This paper investigates the role of the European Central Bank (ECB) in the (mal-) functioning of Europe's Economic and Monetary Union (EMU), focusing on the German intellectual and historical traditions behind the euro policy regime and its central bank guardian. The analysis contrasts Keynes's chartalist conception of money and central banking to the peculiar postWWII German traditions as nourished by the Bundesbank and based on fear of fiscal dominance. Keynes viewed the central bank as an instrument of the state, leading and controlling the financial system and wider economy but ultimately an integral part of, and controlled by, the state. By contrast, the "Maastricht (EMU) regime" (of German design) positions the central bank as controlling the state (and disciplining labor unions, too). The paper identifies a number of potential weaknesses that could undermine the euro's guardian of stability, and ultimately the euro itself. Essentially, the national success of the Bundesbank model in pre-EMU times has left Europe stuck with a policy regime that is wholly unsuitable for the area as a whole. As the general perception in Germany today is that the euro crisis has confirmed the soundness of the key "stability-oriented" principles and ideas behind the euro regime, and of the virtuousness of Germany's own conduct under that regime in particular, it is hard to see how Europe might escape doom through regime reform and policies that would need to permanently put to rest Bundesbank wisdom.
\end{abstract}

Keywords: Central Banking; Bundesbank; Ordoliberalism; Economic and Monetary Union; Euro Crisis

JEL Classifications: B22, E58, E61, E65 


\section{INTRODUCTION}

This paper sets out to investigate the role of the European Central Bank (ECB) in the (mal-) functioning of Europe's Economic and Monetary Union (EMU), focusing on the German intellectual and historical traditions behind the euro policy regime and its central bank guardian. We find that the national success of the Bundesbank model in pre-EMU times has left Europe stuck with a policy regime that is wholly unsuitable for the area as a whole. As the general perception in Germany today views the euro crisis as confirmation of the soundness of the key "stability-oriented" principles and ideas behind the euro regime, and of the virtuousness of Germany's own conduct under that regime, in particular, it is hard to see how Europe might escape doom through regime reform and policies that it would need to permanently archive Bundesbank wisdom.

The analysis begins in section 2 with a contrast of Keynes' chartalist conception of money and central banking and the peculiar post-World War II German traditions nourished by the Bundesbank and based on fear of fiscal dominance; the latter conception is then explored in more detail in section 3. Keynes presents the central bank as an instrument of the state, leading and controlling the financial system and wider economy, but ultimately an integral part of, and controlled by, the state. By contrast, the "Maastricht (EMU) regime" (of German design) positions the central bank as controlling the state (and disciplining labor unions, too). The Bundesbank's peculiar powers were hardly derived from nor backed by (old) liberal thinkers such as Eucken, Friedman, or Hayek, but were founded in German monetary mythology instead. Ironically, despite - or rather because of - all the precautions taken by the regime designers to make the ECB super strong, section 4 identifies a number of potential weaknesses that will tend to undermine the euro's guardian of stability, and ultimately the euro. Essentially mercantilist in character, the Bundesbank's exclusive price stability focus provided Germany with a competitive edge as long as others behaved differently and provided the export stimulus. While - indirectly — causing growth in Germany in pre-EMU times, transferring the model onto the region leaves the ECB afflicted with an anti-growth bias, especially since fiscal policy across Europe is also calibrated against growth. Section 5 reviews three episodes that illustrate the ECB's anti-growth bias at work. Section 6 then discusses the ECB's firefighting role in the crisis, highlighting the limitations faced by a central bank that is not backed by a state. Finally, 
section 7 offers some concluding observations on reforming the dysfunctional Maastricht regime.

\section{CONTRASTING CONCEPTIONS OF CENTRAL BANKING}

Historically, central banking functions have spanned serving as government banker and bankers' banker. The former role focuses on public finances and features debt management, currency issuance, and development finance, for instance, while the latter focuses on banking stability and features payment system robustness, bank supervision, and last-resort lending, in particular. The government banker part draws attention to the historical link between central banking and public finance (or "fiscal policy"), with seigniorage - and the potential for "inflation tax" abuses - as one focal point in monetary theory, while the bankers' banker part highlights the inherent instability in the joint-production business of deposit-taking and credit creation. Historically, the bankers' banker role required the central bank's withdrawal from competition with its bank clients (Goodhart 1998). The two central banking spheres of public finance and banking stability are intertwined in many ways, as they are with central banks' more recent role in monetary policy.

While stabilizing the exchange rate and managing gold convertibility may be seen as a prototype of monetary policy, in Germany understood as "safeguarding the currency" at the time, central banking as deliberate interest rate management (or "monetary policy" proper) aimed at stabilizing aggregate economic activity and prices, in general, only gained full currency since the "Keynesian revolution" with newly enacted full-employment legislation in the post-World War II era (Capie et al. 1994). In general, Keynes's name is narrowly associated with monetary policy as a tool for aggregate demand management. But his monetary thought actually evolved around the full trinity of central banking roles.

Most importantly, Keynes always embraced central banking as an organ of the state and instrument of public policy, an instrument to be applied diligently to ensure government control over the currency, public finances, financial stability, as well as economic stability. In Indian Currency and Finance, Keynes (1913) focuses on the risks to banking stability that the absence of a central bank entails, emphatically endorsing the Bagehot principle. A Tract on Monetary Reform has Keynes (1923) argue that the Bank of England's policies, to be carried out in close cooperation with the Treasury, should focus on domestic stability rather than any external 
commitment (gold, etc). Monetary policy as a source of and an instrument to counter and contain the business cycle is then analyzed in depth in A Treatise on Money. This is the work in which Keynes (1930, p. 4) embraces chartalism as the "doctrine that money is peculiarly a creation of the State.” The deliberations leading to the Macmillan report of 1930 see Keynes emphasizing the crucial role of the central bank in controlling the banks. Similarly, in The General Theory, the central bank appears as one of the "central controls" applied to leading the financial system and stabilizing the economy. Finally, confronted with the public debt legacies of WWII, Keynes' post-General Theory focus is on central bank-Treasury cooperation in monetary policy and debt management. While Keynes granted a certain scope for central bank independence in protecting the monetary technicians' expertise in the pursuit of their prescribed duties, central bank policies were to be an integral part of general economic policy as determined by the government of the day within the space provided by law and accountable to parliament (Bibow 2002b, 2009c).

Keynes's main conservative rivals, Milton Friedman and Friedrich August von Hayek, fundamentally challenged the Keynesian vision of central banking. Friedman went along with Keynes in seeing the central bank as a powerful public instrument that could be applied to stabilize the economy. But to him, the true task was to stabilize government, particularly monetary policy, and thereby the economy. He thus parted company with Keynes and set out to design an auto-pilot regime for monetary policy to satisfy his concern to minimize the scope of central bankers' discretion in monetary policy (Friedman 1960). Hayek held Friedman's autopilot idea for controlling the money supply as equally unfeasible as Keynes's idea of deliberate management by competent technicians. The thrust of Hayek's (1975) proposals was to dismantle any government monopoly powers in the spheres of currency and banking and introduce market competition instead. Rejecting discretion as a matter of principle, neither Friedman nor Hayek had any sympathy for central bank independence.

One may also add here the German economist Walter Eucken, leader of the German (Freiburg) school of "ordo-liberalism," to the list of prominent conservative opponents of Keynes. Especially since claims exist that Eucken and ordo-liberalism may have provided the theoretical foundation for the Bundesbank's independence, serving as blueprint for the ECB and as the intellectual inspiration for "stability-oriented" monetary policies as practiced by the Bundesbank and as later emulated by the ECB. Eucken's (1952) views were closer to Friedman than Hayek in spirit, featuring the aim of implanting an "automatically working monetary 
stabilizer" into the monetary system. Essentially, Eucken, too, did not want to rely on independent central bankers' interest rate policies in effectuating his postulate of a "primacy of currency policy," but he did not quite share Hayek's faith in the effectiveness of market competition and law in the currency and banking spheres, either.

Much in conflict with competing (old) "liberal" ideas in this area, monetary policy as conducted by central banks around the world today - including the ECB - is essentially Keynesian in nature. The Keynesian nature of following the "reaction function approach" (Allsopp and Vines 1998) consists of applying judgment in deliberately adjusting interest rates in response to changing circumstances with a view to stabilizing the economy. ${ }^{1}$ By contrast, conservative (neo-classical) ideas prevail regarding the supposed functioning of the economy, faith in "liberalized" and "flexible" markets, and in the money neutrality postulate (and related loanable funds theory of interest), in particular. In practice, important differences may be observed among central banks concerning the ways they interpret and perceive their own role and policies. The next section zooms in on the intellectual roots and historical experiences behind the institutional setup and policies of the ECB.

\section{ON THE CONCEPTION OF THE ECB AS THE EURO'S GUARDIAN AND “STABILITY-ORIENTED" MONETARY POLICY}

Naïve mainstream interpretations of the Maastricht regime with its peculiar status reserved for the ECB may wish to credit the New Classical "time-inconsistency" literature. But that would be missing the point by far. Germans had "known" — and were taught to believe, most tirelessly by the Bundesbank itself - for many decades that the central bank had to be "independent" and price stability its "primary" pursuit for the currency to be properly "safeguarded" (safeguarded from whom is to be clarified in the following). On the other hand, while cursory references to the role of the Bundesbank as the supposed blueprint for the ECB and German exceptionalism

\footnotetext{
${ }^{1}$ Perhaps the case may be made that the approach is Wicksellian rather than Keynesian in nature, as suggested by Woodford's (2003) "Interest and Prices: Foundations of a Theory of Monetary Policy," a work published in the heydays of inflation forecast targeting. Yet neither was Wicksell the first author to observe the connection between interest, credit, and prices. Wicksell's contribution in this area concerned cumulative processes, based on a vision of fluidity of prices. Keynes, in the 1930s, generalized the perspective by recognizing that real ("monetary production") economies defy the money neutrality postulate, an insight misconstrued in the mainstream literature under the heading of "rigidities" as hampering otherwise fluid prices and smoothly working market adjustment mechanisms. In recognition of war-time realities and post-war prospects of public debt legacies and related debt management requirements, Keynes came to favor less active use of interest rate policies but even closer cooperation with the fiscal authorities in the 1940s.
} 
regarding price stability are quite frequently made, the extent and nature of the German influence on the design of the Maastricht regime of the EMU and their historical background in German monetary history remain generally underappreciated.

To begin with, the Maastricht regime really is largely a "made in Germany" product. The committee charged with drafting the Maastricht regime consisted mainly of central bankers, including the then Bundesbank president Karl-Otto Poehl, negotiating within the constraints set by his colleagues on the Zentralbankrat, including hardliners like Helmut Schlesinger (later interim Bundesbank president at the time of the exchange rate mechanism-ERM-crises). Helmut Kohl, German Bundeskanzler at the time, understood well that he had to make sure to have the Bundesbank "on board" in selling the euro to a skeptical German public, unenthusiastic to give up the beloved deutsch mark, precluding any concessions to European partners that would not meet the Bundesbank's approval. Furthermore, Germany was the only euro aspirant country left that actually still had to surrender its monetary sovereignty. As members of the ERM following the Bundesbank's lead in monetary policy, others had long done so anyway. This, too, put Germany in a strong negotiating position. Essentially, the Bundesbank was in a position to dictate the conditions of its own abdication of power in pulling the monetary strings in Europe. The conditions laid down were such that probably not even Bundesbank believed that Europe might sign up. The fact that the design of EMU "made in Germany" was accepted is foremost evidence of the degree of desperation existing elsewhere in overcoming Bundesbank supremacy. To nations other than Germany, the euro held out the prospect of ending regional hegemony and partially regaining (shared) monetary sovereignty.

So what, then, is the true nature of the Bundesbank's legendary independence and the supposed "primacy" of price stability? In answering this question I will provide an exploration in what I call "Bundesbank mythology," the set of myths nourished in post-war Germany that capture the German belief system about money and monetary policy. I will begin with ordoliberalism as its supposed theoretical foundation. Otmar Issing, the ECB's first chief economist (1998-06), who had previously held the same position at the Bundesbank (1990-98), offers his thoughts on the matter in a speech titled "On the primacy of price stability," in which he suggests that claims of parenthood for the euro would be quite in order in the case of Walter Eucken:

Walter Eucken's notion of the primacy of monetary policy — and thus of price stability — as the very foundation of a functioning market economy also lies at 
the heart of monetary union in Europe. ... Walter Eucken is admittedly not a name that springs immediately to mind when searching for the intellectual antecedents of the euro. However, he stands for a school of thought which provided a source of inspiration to many economists and central bankers who have incessantly insisted on the importance of stability as the condition sine qua non for a successful single currency. The ordo-liberal tradition represented eminently by Walter Eucken (and colleagues in Freiburg and elsewhere) has had a substantial influence in shaping the post-war economic order in Germany emphasizing the importance of market competition and stable money. In the monetary field this found its expression in the setting up of the Bundesbank as an independent institution dedicated to safeguarding the value of the currency.

(Issing 2004, p. 4)

Eucken's (1952) “Grundsätze” actually referred to the primacy of “currency policy” and made it very clear that Eucken wholeheartedly distrusted central bankers' discretion in setting interest rates, which is why he aspired to implant an "automatically working monetary stabilizer" into the currency order. Moreover, Eucken (1946) rejected the idea that central bank independence would include the right of the central bank to oppose government policy, as this would contradict his "principle of unity of economic policy." Certainly from the viewpoint of the history of ideas, Issing's reading of Eucken as the source of the "primacy of monetary policy_and thus of price stability," which would allegedly require an "independent" institution dedicated to just that, seems extraordinarily "liberal." But that is not the point here. ${ }^{2}$ Rather, the point is that Issing correctly describes the predominant German belief system on this matter, namely the myth that there exists a well-founded theory in German economic thought justifying both the Bundesbank's independence and its preoccupation with price stability. It is always good to have science on one's side. ${ }^{3}$

A second Bundesbank myth concerns German exceptionalism in matters of inflation phobia. Johnson (1998, p. 199) observed that the Bundesbank conducted "orchestrated efforts to reinsert memories of the hyperinflation of the 1920s into Germanys' postwar political mythology." Actually, the Bundesbank went even further in effectively rewriting German monetary history as featuring two hyperinflations within one generation. While the Great Depression was somehow deleted from collective memory, Nazi Germany’s Total War was turned into a monetary phenomenon that primarily wiped out German savers. Hence the independent institution protecting German savers is deserving of glorification and untouchable

\footnotetext{
${ }^{2}$ Bibow (2009a; 2010) deal with this issue in depth.

${ }^{3}$ Issing is therefore generous with his praise of the time-inconsistence literature (finally the Anglo-Saxons got the point, too ... catching up with German monetary wisdom ...).
} 
status. A disgraceful historical fiction, but it worked rather well for the Bundesbank, as the following quotation from its former president Hans Tietmeyer (1991, p. 182) nicely captures:

The reasons for the success of German monetary policy in defending price stability are in part historical. The experience gained twice with hyperinflation in the first half of this century has helped to develop a special sensitivity to inflation and has caused the wider public to believe in the critical importance of monetary stability in Germany. For this reason, the strong position of the Bundesbank is widely accepted by the general public — questioning its independence even seems to be a national taboo. This social consensus has yielded strong support for the policy of the Bundesbank.

We may add that writing the Great Depression and German deflation out of the play (and blaming Hitler for the Weimar hyperinflation ${ }^{4}$ ) is the source of much irritation in global policy cooperation today. Wolfgang Schäuble, Germany’s finance minister since 2009, illustrates the point well, identifying

two different approaches to economic policymaking on each side of the Atlantic. While US policymakers like to focus on short-term corrective measures, we take the longer view and are, therefore, more preoccupied with the implications of excessive deficits and the dangers of high inflation. So are German consumers. This aversion to deficits and inflationary fears, which have their roots in German history in the past century, may appear peculiar to our American friends, whose economic culture is, in part, shaped by deflationary episodes. Yet these fears are among the most potent factors of consumption and saving rates in our country. Seeking to engineer more domestic demand by raising government borrowing even further would, here at least, be counterproductive. On the contrary, restoring confidence in our ability to cut the deficit is a prerequisite for balanced and sustainable growth. ${ }^{5}$

Again, however, unbelievable as it may seem to an outsider, Schäuble correctly describes the predominant German belief system on the matter. While German $20^{\text {th }}$ century monetary history was actually rather symmetric, featuring both hyperinflation and deflation, Germany's “economic culture" today, in contrast to America's, is highly asymmetric (not "shaped by deflationary episodes"). Germany's peculiar "economic culture"-adoringly referred to at home as its "stability culture" - is closely aligned with the key peculiarity about

\footnotetext{
${ }^{4}$ Issing's favorite quotation on this issue is from the Austrian writer Stefan Zweig: "We must always remember that nothing rendered the German people so embittered, so full of hatred, so ready for Hitler, as inflation." (See Issing (2004, p. 3, for instance.) The problem with Mr. Zweig's personal perceptions - that seem to suit Mr. Issing's own ideological presuppositions and political instincts as independent central bank politician rather well-is that they are not corroborated by election outcomes, which show fairly low and declining support for Hitler's National Socialist German Workers Party (NSDAP) in the 1920s, surging (together with extremism on the left) only with the onset of the Great Depression and rising unemployment. See Kolb 2005.

${ }^{5}$ Wolfgang Schäuble, "Maligned Germany is right to cut spending," Financial Times, June 23, 2010.
} 
German-style monetary policy: a conspicuous asymmetry in mindset and approach. German central bankers have a special gift for detecting inflation risks even when nobody else can, but they are never really scared of deflation.

Germany's "price stability above all else" monetary anthem is more gently referred to as "stability-oriented" monetary policy. And mainstream economists continue to have a hard time coming to grips with the substance of the notion of "stability-oriented," which really stands for the Bundesbank's (and later ECB's) “price-stability-only” approach to monetary policy. The Bundesbank approach to interest rate policy may be likened to a driver who is always ready to slam the brakes but never willing to kick down the accelerator. Importantly, German-style monetary policy is not stabilization policy (associated with "fine tuning" and “interventionism"), but "stability policy" instead (associated with "ordo" or "Ordnungspolitik"). By conception, stability policy is all about preventing inflation, not about attempting to directly stimulate growth and employment.

A third crucial Bundesbank myth appears here: the myth that price stability itself somehow causes growth. ${ }^{6}$ This myth is related to the conundrum of how the Bundesbank's peculiarly asymmetric approach to monetary policy could possibly not give rise to an antigrowth bias in Germany. It is important here to consider international and regional monetary arrangements and external price competitiveness vis-à-vis Germany's trading partners. The point is that by keeping inflation at a lower level than in trading partners, while operating within regimes of pegged nominal exchange rates, first within the Bretton Woods regime of dollar pegs, then within the exchange rate mechanism of the European Monetary System with its de facto deutschmark anchor, maintaining price stability did actually cause German growthnamely by boosting the country's competitiveness and exports. Loathing the idea of stimulating growth and employment directly, Bundesbank-style "stability-oriented" monetary policy leaves the tricky part of the job for others to look after, with a "wait and see" until exports would pull Germany along approach. Similarly, apart from operating with a kind of safety net provided by labor market institutions that make wage declines unlikely, the part of taking out insurance against deflation risks could also be conveniently left to others to take care of. The Bundesbank could earn its claim to fame as superstar inflation fighter while Germany could still grow—since price stability did cause growth under these (pre-EMU) conditions. In short, the Bundesbank's

\footnotetext{
${ }^{6}$ The ECB's (1999, for instance) communications feature the assertion that by maintaining price stability, the ECB would thereby also contribute to all other goals.
} 
crucial part within German stability culture was to enforce the discipline that would deliver price stability_-budgetary and wage discipline.

This leads us to the substance of "independence," an issue on which we may again consult the wisdom of Otmar Issing, offering his thoughts on the matter in a speech devoted to another of his idols, titled "Hayek - currency competition and European Monetary Union." Again confronted with the problem that his idol did not really think much of the idea of central bank independence, Issing suggests that:

At another level, one can see many strands in Hayek's thinking that may have influenced the course of the events leading to Monetary Union in subtle ways. What has happened with the introduction of the euro has indeed achieved denationalization of money, as advocated by Hayek, at least in the Euro 11 countries. Furthermore, the euro is being managed by a central bank (the ECB) that is protected from political interference by a Treaty (the Maastricht Treaty), to which all Member States are signatories. All national central banks that comprise the Eurosystem are now independent of their respective Euro 11 governments, and, according to their respective statutes, cannot take instructions from these governments. Moreover, the Eurosystem is supranational and does not therefore have any natural political counterpart in the form of a supranational government with full executive powers. This further underpins the independence of the Eurosystem and enables it to pursue its mandated ultimate objective, that is price stability, without interference from government. Thus, monetary policy in the Euro 11 countries has been denationalized and is being conducted by a supranational central bank, which is politically independent of the governments of the Member States. Furthermore, any monetary financing of the public sector or privileged access to financial institutions are prohibited. The separation between public finance and monetary policy is thereby assured. (Issing 1999, pp. 9-10)

In safeguarding the currency, the separation between public finance and monetary policy is the essence of the matter. Issing's fear of "fiscal dominance" follows the Bundesbank tradition as succinctly expressed by Wilhelm Vocke (1973), long-time President of the Directorate of the Bank deutscher Länder who went on to become the first Bundesbank president in 1957: "every inflation starts in public finances as public expenditures get inflated." Staunchly upholding memories of Weimar and of later "Mefo loans," an arrangement of complete separation is seen as strength. Note, also, that Issing depicts the absence of "any natural political counterpart in the form of a supranational government with full executive powers" as a factor that would strengthen the independent central bank.

Clearly, then, the idea is not for the central bank to be part of government economic policy, but to be totally separated from it. The idea is not of the central bank as a team player in 
pursuit of team goals, but of an individual player (if necessary, an opponent) in pursuit of its own goals. In fact, the position of the central bank in the Bundesbank conception may be best compared to that of a judge or referee: the role of the independent central bank is to discipline other players, finance ministers and unions, in particular. Complementary institutional safeguards are sought in the form of the so-called Stability and Growth Pact and structural reform of labor markets (designed to weaken labor). But the independent central bank is seen as the ultimate control in safeguarding savers' interests.

In conclusion, based on Bundesbank mythology, the Bundesbank conception of central banking differs fundamentally from Keynes's chartalist one. Recognizing the deep interconnectedness of public finances, monetary policy, and financial stability, Keynes's thought evolved within the trinity of central banking roles and he always understood monetary policy as an instrument of the state that was to be an integrated part of economic policy. By contrast, in the Bundesbank's conception, there needs to be a water-tight separation between monetary policy and public finances, with the independent central bank in the role of the referee and enforcer of discipline. ${ }^{7}$ At a superficial level, the Bundesbank's and ECB's interest rate policies may appear to be very similar to other central banks' practices following the Keynesian reaction function approach. However, this would be missing the distinctive asymmetry in mindset and approach that characterizes the Bundesbank and ECB. The point is that this arrangement worked for Germany in the past, running essentially along lines depicted by Keynes in The General Theory as mercantilist. That these arrangements are wholly inadequate for Europe has become clear from the experiences so far, although both the responsible authorities and outsiders continue to have a hard time understanding the root causes of the regime's malfunctioning.

\section{BOTH SUPER STRONG AND EXTRAORDINARILY WEAK}

A brief summary of some key Treaty rules will suffice here (for a more detailed discussion, see Bibow 2002a, 2006a, and 2009b, for instance). The regime designers conceived of manifold safeguards to ensure the peculiar divorce and envisioned water-tight separation between monetary and fiscal policies meant to prevent fiscal dominance and printing press abuse. Both

\footnotetext{
${ }^{7}$ ECB policymakers are always quick to denounce any commentary made by politicians on monetary policy as an attack on their independence while happily considering it to be part of the bank's monetary policy mandate to notoriously call for budgetary discipline, wage restraint, and structural reform.
} 
the ECB and NCBs are prohibited from "monetizing" public debt through direct purchases of public debts. Also denied was privileged access to credit institutions, and additional constraints were put on public debt financing, as well. With budget deficits exceeding 3 percent of GDP generally deemed "excessive" and warranting penalties under the "Excessive Deficit Procedure" (EDP), the so-called Stability and Growth Pact (SGP) requires members to attain a budget "in balance or in surplus" over the cycle. ${ }^{8}$ The "no bail-out" clause complements this set of supposed safeguards, protecting the national partners from each other's fiscal failings, by supposedly containing any national solvency issues at the respective national level at which they might arise.

Given the high degree of revealed distrust of (elected) politicians, it suits the peculiar kind of Bundesbank-style independence that Europe's (unelected) central bank politicians are not facing any effective discipline at all —a situation I dubbed the "Maastricht paradox" (Bibow 2002a). No effective check of the ECB's independent decision-making exists. The bank publishes reports, holds regular press conferences, and its president engages in a "Monetary Dialogue" with a subcommittee of the European Parliament, but none of this publicity might prompt any real consequences for the bank. It therefore seems fair to say that the ECB is the world's most unconstrained (i.e., independent and unaccountable) central bank. Two factors make the ECB's status even stronger than the Bundesbank's. First, while the Bundesbank was only protected by a simple law requiring simple parliamentary majority for change, the ECB's status has constitutional rank since changing it would require a Treaty change (i.e., unanimous agreement of all member countries). Second, related to the element of strength seen by Issing in the absence of a supranational government, the scope for conflicts over exchange rate matters is more limited in the ECB's case - an issue that featured prominently in conflicts between the Bundesbank and the German government in pre-EMU times.

But there are also three potential sources of weakness which may put the world's most unconstrained central bank, intended to be super strong by careful design, into a position of extraordinary weakness.

The first potential source of weakness concerns the role of public support enjoyed by the Bundesbank in Germany at the heyday of her monetary rule over Europe. Recall Tietmeyer's

\footnotetext{
${ }^{8}$ These stipulations go beyond the pre-Maastricht situation in Germany, which allowed for strictly limited access to central bank credit ("Kassenkredit") for the government and featured a fairly flexible "golden rule" for fiscal policy.
} 
observation that questioning the Bundesbank's independence had become a "national taboo." A simple law offers sufficient protection if no government will ever dare to seriously challenge your independence. Yet, the "social consensus" in support of the Bundesbank had not come about over night, but required decades of comprehensive public relations efforts (creating and sustaining those myths discussed above). An important argument used by the Bundesbank (and later by the ECB) concerning accountability is that no accountability vis-à-vis any government body would be required since the bank is directly accountable to the general public. At times, the Bundesbank would seek out opportunities to orchestrate public conflicts with the government as part of its public relations strategy to self-stylize itself in the public's view as the guardian of stability and host of unchallengeable wisdom in the country (see Katzenstein 1987, Marsh 1992, and Johnson 1998). I posit that the Bundesbank's public standing was rather unique and that German exceptionalism in this matter will not be easily exportable to Europe. There is much more of a challenge in this issue for the ECB than simply earning the reputation as a tough inflation fighter.

And this is where the second potential source of ECB weakness arises. What made it easier for the Bundesbank to establish its reputation as inflation fighter no. 1 and its broader "untouchable" and unchallengeable status was the fact that being tough on inflation did not represent a general obstacle to growth, since price stability actually did cause growth in Germany under pre-EMU conditions. This will not be the case for the euro area, which is far too large and too closed to successfully pull off what is an essentially mercantilist growth strategy.

Related to the Bundesbank mythology discussed above, deep-seated confusions characterize German policy thinking on the matter of national competitiveness. In the German mind, competitiveness gains and trade surpluses are a sign of moral virtue. In misapprehension of the fact that competitiveness is always relative and that trade surpluses presuppose trade deficits for their very existence, the latter are seen as a sign of moral failing. Germany has yet to understand that the success of the mercantilist German model in pre-EMU times was dependent upon others behaving differently. The grand illusion was that by exporting the German model to Europe, it would work even better for everyone.

The problem for the ECB arising from these confusions and illusions is that the ECB is operating within a policy regime that is utterly dysfunctional for Europe. Unaware of the true causes of its troubles, the ECB is bound to be fighting an uphill struggle in delivering on anything else but price stability — which will make it all the more important for the bank to 
distance itself from anything else but price stability. But it will also doom the ECB in emulating the Bundesbank's route to public glorification unless the European public really does not care about anything other than price stability. That Europeans may suffer from permanent money illusion is not a safe assumption. This second source of potential ECB weakness stemming from the Maastricht regime's dysfunctionality will be the subject of next section 5 .

But a potentially even more serious source of weakness arises in situations that critically require operating in partnership with a government counterpart for their resolution - a partner that does not exist. The supposed strength of complete separation between monetary and fiscal policies may turn out to be a fatal weakness. This issue leads us back to the chartalist conception of central banking and will be the subject of the subsequent section 6 .

\section{ECB'S ANTI-GROWTH BIAS AND PRE-CRISIS PERFORMANCE}

The SGP requires balanced budgets over the course of the cycle. Unless offset by strong-enough private borrowing or export surpluses, fiscal policy is thus afflicted by an anti-growth bias. At best, the SGP allows for the free working of automatic stabilizers. In practice, it does not, and fiscal policy in Euroland is procyclical as a result, which is making the growth predicament even worse. Add the ECB's asymmetry and hence inherent anti-growth bias in monetary policy into the picture, and it becomes clear why Euroland is unlikely to enjoy long booms, but more likely to get stuck in protracted domestic demand stagnation instead. Growth will largely depend on the strength of global growth and the euro exchange rate. It is therefore not at all surprising that the Euroland business cycle features brief booms and long stagnations together with a degree of export dependence that is unusual for an economy of its size.

This section will briefly discuss three episodes in the euro's first decade of existence that exemplify serious policy blunders involving the ECB. The first episode features the euro's plunge in 1999-2000. The part of the ECB in this episode was to clash with the markets. The second episode then produced the unflattering phenomenon of "tax-push inflation" that arose in the period of protracted stagnation, 2001-05. The part of the ECB in this episode was failure to internalize fiscal policy, which - despite operating in a regime of monetary dominancegenerated "some unpleasant Keynesian arithmetic." 9 The third episode also began in earnest in

\footnotetext{
${ }^{9}$ Notice the irony that this is turning the classic essay, "Some Unpleasant Monetarist Arithmetic," by Sargent and Wallace (1981) upside down. Bibow (2007b) identifies an earlier episode of tax-push inflation with extraordinarily
} 
the years of protracted stagnation and leads us straight to the internal euro crisis that began in 2008-09. The ECB's role in this episode was to give its warm blessings to divergences that were bound to undermine the euro in due course.

In essence, the euro's plunge in 1999-2000 resembled the experience in many emerging market economies that interest rate hikes may end up weakening rather than bolstering the currency when financial markets perceive the tightening as undermining growth. With markets anticipating that a weak economy will require lower rates beyond the immediate horizon, the authorities run into a time-inconsistency problem, and the measure lacks credibility and backfires. In this case, the ECB failed to read and communicate with the markets. Operating in a general climate of growth enthusiasm (final stage of the dot.com boom) and up against the progrowth Greenspan Fed, the ECB's monotone "price stability above all else" anthem and the aggressive interest rate hikes it inspired (the ECB nearly doubled its policy rates within less than a year) did not bode well with the markets. The markets' thumbs down in terms of the euro's plunge dealt the ECB a heavy blow since it had the unwelcome effect of pushing up inflation from its very low level at the euro's launch to well above the ECB's tolerance level of 2 percent. The situation continued into 2001 when the Fed's fast-track easing vs. the ECB's "wait and see" also had the effect of keeping the dollar up and the euro down. This episode was not to be the last one offering the lesson to the ECB that paying insufficient attention to growth can backfire on both growth and price stability - that vital lesson that the ECB stubbornly refuses to learn.

The legacy of the euro's plunge — headline inflation well above 2 percent-led straight into the period of protracted stagnation that befell Euroland in the years 2001-05. As Euroland failed to emerge from the global slowdown of 2001, with the ECB practicing "wait and see" in easing its stance, much in contrast to the brisk tightening earlier, this triggered the SGP in numerous countries as government budgets hit the 3 percent ceiling. Laboring under "Excessive Deficit Procedures," fiscal retrenchment included many measures that artificially distorted headline inflation upwards (e.g., increases in indirect taxes and administered prices). This "taxpush" distortion was quantitatively very sizeable and kept headline inflation persistently above 2 percent; notoriously, but wrongly, blamed on alleged structural problems. A measure of core

high collateral damages in the case of Germany following unification. A little known fact is that West German consumer price inflation excluding tax push peaked at below 3 percent in 1992. The Bundesbank's response to Germany's historical unification challenge is well-known: monetary overkill, setting the scene for German stagnation in the 1990s, followed by the strategy of national wage restraint to "restore" competitiveness that undermined the euro. 
inflation that excludes tax-push shows how "market-determined" underlying inflationary trends in Euroland declined towards very low levels in this period (Bibow 2006c). By failing to properly internalize fiscal policy, the ECB once again harmed both growth and price stability. This counterproductive interaction of monetary and fiscal policies highlights how very dysfunctional the Maastricht regime really is: Fixated on their respective magic numbers (2 percent for the ECB, 3 percent for the fiscal authorities), both numbers are missed as growth is being suffocated.

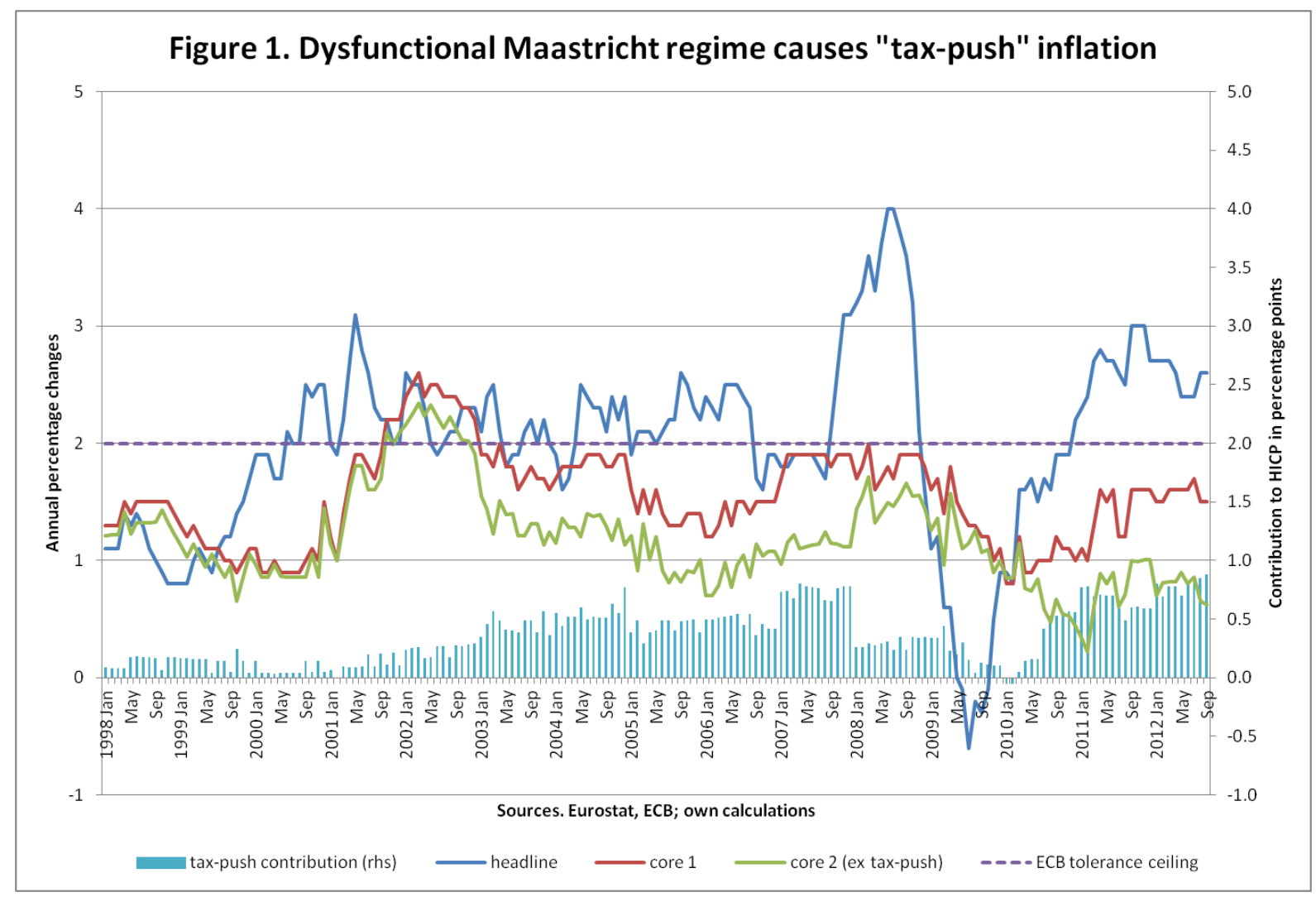

While tax-push is again a major factor today as countries impose mindless austerity on their struggling economies, the third blunder, coinciding with the second episode, provides the background for today's crisis. The matter can be put very simply. The ECB's definition of price stability as "below but close to 2 percent" provides a stability norm for wage trends. As a kind of "golden rule" of a monetary union, national wage trends corrected for productivity (i.e., unit labor costs) cannot stray from this stability norm for long without causing imbalances. With nominal exchange rates gone, unit labor cost trends determine whether intra-area real exchange 
rates stay in balance. As Germany diverged from its own historical 2-percent stability norm under the euro regime, competitiveness positions inside the currency union ran seriously out of kilter and imbalances built up. Moreover, diverging wage trends also undermined the "one-sizefits-all" monetary policy. As wage restraint depressed consumption and raised inequality in Germany, the ECB's uniform nominal interest rate also meant relatively tighter financial conditions in Germany, magnifying divergence further, as the opposite would be the case in countries with above-average inflation, such as booming and bubbling Spain and Ireland.

The remarkable thing is not only that the ECB completely failed to detect the bubbles in Euroland's booming economies. Far worse is that diverging wage trends were interpreted as an equilibrating mechanism. Unwarranted wage restraint in Germany was the very cause of domestic demand weakness - not the consequence, as fallaciously interpreted by the ECB. In the ECB's view, the "competitiveness channel" would counteract diverging wage-price inflation trends and somehow operate in an equilibrating fashion (ECB 2005). Completely aloof from the troubles that were brewing in Euroland, in the spring of 2005, Otmar Issing (2005) proudly proclaimed:

On the eve of the changeover, I wrote a commentary on diversity and monetary policy in the euro area. To the question whether a single one-size monetary policy could fit all parties involved — be they national entities, social partners or economic actors - my answer was: 'One size must fit all'. The political decision on the creation of EMU had resolved all discussions on whether monetary union should precede or follow political unity and the fulfillment of the criteria for an optimum currency area. Today, in light of the evidence gathered so far in the euro area, I am more confident in saying: 'One size does fit all!'

The ECB's chief economist could not have been further off the mark. Intra-area current account imbalances and the corresponding internal imbalances and financial fragilities would continue to soar until 2007, but then unravel brutally in 2008-09 as the global crisis triggered a bursting of internal bubbles-leaving debt overhangs in their trail that are the background to the ongoing euro debt crisis. In due course Greece, Ireland, Portugal, and Greece once again received "bailout loans" controlled by the "Troika" (of ECB, European Commission, and IMF) and involving the European Financial Stability Facility (EFSF). On June, 9 2012, a bailout for the Spanish banking system was negotiated.

The Bundesbank was again glorified since inflation fighting caused growth in Germany. It is hard to see how Europeans develop a true love for their currency and its guardian as these 
become more and more associated with stagnation and crisis. Will the ECB be lauded for saving the euro instead?

\section{EURO DEBT CRISIS AND THE ECB AS THE EURO'S SAVIOR?}

Signs of stress in financial markets emerged early on in 2007, acutely intensifying on August 9, 2007. The ECB exhibited a split personality in response. On the one hand, the bank flexibly adapted its operating procedures in response to emergency liquidity needs (e.g., switching to "fixed rate full allotment" tender procedures in its repo operations, including longer maturities, and at watered-down collateral requirements, etc.). On the other hand, the ECB remained preoccupied with perceived inflation risks and merely interrupted its tightening cycle after the hike in June 2007, keeping up its continued tightening intentions on which it followed through with a final hike in July 2008. The Euroland economy had entered recession in the spring quarter, but the first ECB rate cut only came on October 8, 2008 (as part of an internationally coordinated policy easing by key central banks). Further rate cuts followed in the face of a collapsing economy and the ECB's key policy rate eventually reached 1 percent by May 2009. The "slow to ease, quick to hike" mindset showed all over again as the bank hiked again in April and July 2011, perceiving upward inflation risks ahead of everyone else. These premature hikes were reversed under the new ECB president Mario Draghi before the 2011 year-end, whose arrival also marked other more fundamental changes.

Until that time, the ECB's crisis response had been rather timid by international comparison, both in terms of its interest rate easing and especially regarding any active measures for balance sheet expansion (beyond its passive provision of emergency liquidity to banks). Two special programs of limited size had previously been initiated by the ECB, officially in view of dysfunctional market segments that were hindering the monetary transmission mechanism. The first was announced in May 2009 in support of banks and covered bonds with a volume of up to $€ 60$ billion, and the second in May 2010 in support of private and sovereign debt securities. The volume of the latter reached about $€ 70$ billion by mid 2011 , with support targeting the Euro crisis countries. Starting in early August 2011, and until early 2012, the volume of the securities market programme (SMP) surged to $€ 220$ billion, now also including purchases of Italian and Spanish sovereign debt securities. The purchase of public debt under the SMP has proved highly controversial for the ECB, and the resignation of two 
Bundesbankers occurred in this context (Bundesbank president Axel Weber and ECB Executive Board member Jürgen Stark) — despite the fact that the ECB only purchased bonds in the secondary market (not "directly" in primary markets) and also fully "sterilized" the liquidity effects of its measures under the SMP (so as to uphold the appearance of not "monetizing" public debt or using the "printing press").

The ECB then changed course with Draghi's initiation of two large-scale "Long Term Refinancing Operations" (LTRPs), flooding banks with $€ 1$ trillion three-year liquidity in December 2011 and February 2012, which had the net liquidity effect of boosting the ECB's balance sheet by some $€ 500$ billion. These quantitative easing measures achieved some temporary calming of financial conditions, encouraged some public debt purchases by banks, and saw small declines in the volume of the SMP. The LTROs confirmed that the ECB lends a (last-minute) supporting hand to the euro when market conditions reach crunch time and governments fail to agree on political/fiscal support.

Apart from short-lived market excitement or mere relief, the point is that the ECB cannot solve the underlying euro debt crisis but only buy governments some time anyway. In essence, the euro debt crisis is a twin banking and intra-area balance of payments crisis. Unbalanced competitiveness positions and intra-area current account imbalances give rise to debt flows for as long as they persist. One issue - the flow issue - is that sizeable imbalances do still exist and now require official lending as private lending is no longer forthcoming. Another issue - the stock issue - is the problem of working off the legacies of debt overhangs. The crisis is made worse by asymmetric fiscal retrenchment in crisis countries together with large-scale capital flight. The former pushes debtor countries into a full-blown debt deflation. The latter threat shows up as TARGET2 imbalances within the Eurosystem.

As a result of running persistent current account surpluses in the 2000s, Germany has accumulated net foreign assets of around $€ 1$ trillion, concentrated in the euro area. Until now, German banks and other financial institutions were largely responsible for the capital flight from crisis countries towards Germany, and their withdrawal of commitment (non-rollover of interbank loans, etc.) was made possible without taking a hit by the ECB's LTROs. German private risks were thereby transferred onto the Bundesbank's balance sheet, where they are conveniently mutualized among euro partners (assuming Germany has any partners left to share losses with). The Bundesbank’s creditor position within the Eurosystem reached some $€ 730$ 
billion by mid-2012. There is scope for further capital — including deposit—flight towards the German haven.

Highlighting the "centrality of the link between political sovereignty and fiscal authority, on the one hand, and money creation, the mint and the central bank, on the other," Goodhart (1998, p. 409-10) observed that chartalists "worry whether the divorce [between the main monetary and fiscal authorities] may not have some unforeseen side effects." Indeed, while the crisis may force the ECB to expand its balance sheet still further, TARGET2 imbalances are ultimately fiscal liabilities. The euro regime can survive banking crises for as long as they are national and small enough not to undermine national fiscal solvency. And the euro regime could survive perpetual trade imbalances too if these were sponsored by fiscal transfers. By prohibiting transfers but failing to prevent trade imbalances, the euro regime has left the ECB overburdened in cleaning up alone (except for the EFSF/ESM) after large-scale debt overhangs and cross-border banking crises. Technically, the ECB's balance sheet may bear far more. But without a Treasury or State behind it, that balance sheet may soon fail to inspire trust among the public, the markets, or the body politic.

Ultimately, water-tight separation between fiscal and monetary policies and the vacuum left by the nonexistent European fiscal authority do not strengthen but threaten the euro's survival - and hence its guardian, too. The markets may call the bluff behind ECB liquidity faster than the political process — acting under numerous constraints at this point—can react.

\section{CONCLUDING REMARKS}

Europe's monetary union has been ill-designed and dysfunctional from the beginning. Market rigidities and fiscal profligacy have not brought the crisis upon Europe, but the absence of domestic demand management and the failure to prevent the buildup of intra-area divergences and imbalances have. Today, regime reform towards these ends is complicated by severely unbalanced competitiveness positions and debt overhang legacies. Refocusing the ECB on growth and price stability would have to be a part of any solution; refocusing area-wide fiscal policy on growth and investment another.

For ideological reasons (those Bundesbank myths), Germany is blocking any sensible initiative for domestic demand management. Europe's economic constitution has the ECB focused on price stability only, and the "strengthened" so-called Stability and Growth Pact and 
the new "Fiscal Compact" will tie fiscal policy to a constitutionally anchored balanced-budget rule. In addition, a new "Macroeconomic Imbalance Procedure" was designed to asymmetrically punish deficit countries for their moral failings. Essentially, failure to understand why the German model worked for Germany in the past and why it cannot work for Europe today is turning the region into a giant mercantilist block and global destabilizer. The German mindincluding public opinion, political elite, media, etc.--is deeply stuck in an intellectual trap that does not allow for seeing any flaw in the German model. Decades of Bundesbank mythology and brainwashing have done this. 


\section{REFERENCES}

Allsopp, C. and D. Vines. 1998. "The Assessment: Macroeconomic Policy after EMU.” Oxford Review of Economic Policy 14(3): 1-23.

Bibow, J. 2001. "Making EMU Work: Some Lessons from the 1990s." International Review of Applied Economics 15(3): 233-259.

_ 2002a. "The Markets Versus the ECB, and the Euro's Plunge." Eastern Economic Journal 28(1): 45-57.

_ 2002b. "Maynard Keynes on Central Banking and the Structure of Monetary Policy." History of Political Economy 34(4): 749-787.

_ 2004. "Assessing the ECB's Performance since the Global Slowdown." Working Paper No. 409. Annandale-on-Hudson, NY: Levy Economics Institute of Bard College..

_ 2006a. "Europe's Quest for Monetary Stability: Central Banking Gone Astray." International Journal of Political Economy 35(1): 24-43.

—. 2006b. "The Euro Area Drifting Apart - Does Reform of Labor Markets Deliver Competitive Stability or Competitive Divergence?" In Structural Reforms and MacroEconomic Policy, ETUC, 76-86.

_ 2006c. "Inflation Persistence and Tax-Push Inflation in Germany and the Euro Area: A Symptom of Macroeconomic Policy Mismanagement?” IMK Study, 1/2006.

— 2007a. "How the Maastricht Regime Fosters Divergence as Well as Instability." In: P. Arestis, E. Hein and E. Le Heron (Eds.) Monetary Policies - Modern Approaches. Basingstoke: Palgrave Macmillan.

— 2007b. Bad for Euroland, Worse for Germany - The ECB's Record.” In: J. Hölscher (Ed.) Germany's Economic Performance: From Unification to Euroisation. Basingstoke: Palgrave Macmillan.

—. 2009a. "On the Origin and Rise of Central Bank Independence in West Germany." European Journal of the History of Economic Thought 16(1): 155-90.

- 2009b. "The Euro and Its Guardian of Stability: The Fiction and Reality of the 10th Anniversary Blast." Working Paper No. 583. Annandale-on-Hudson, NY: Levy Economics Institute of Bard College. Forthcoming in L.-P. Rochone (Ed.) Monetary Policy and Crisis. Cheltenham, UK: Edward Elgar.

_.2009c. Keynes on Monetary Policy, Finance and Uncertainty: Liquidity Preference Theory and the Global Financial Crisis. London, UK and New York, NY: Routledge.

— 2010. Zur (Re-)Etablierung zentralbankpolitischer Institutionen und Traditionen in West-Deutschland: Theoretische Grundlagen und politisches Kalkül (1946-1967). In: C. 
Scheer (Ed.) Die deutschsprachige Wirtschaftswissenschaft in den ersten Jahrzehnten nach 1945, Band XXV Studien zur Entwicklung der ökonomischen Theorie. Berlin, Germany: Duncker \& Humblot.

—. 2012. "The Euro Debt Crisis and Germany's Euro Trilemma." Working Paper No. 721. Annandale-on-Hudson, NY: Levy Economics Institute of Bard College.

Capie, F., C. A. E. Goodhart, and N. Schnadt. 1994. "The Development of Central Banking.” In F. Capie, S. Fischer, C. Goodhart, and N. Schnadt (Eds), The Future of Central Banking: the Tercentenary Symposium of the Bank of England. Cambridge, UK: Cambridge University Press.

Dyson, K. and K. Featherstone 1999. The Road to Maastricht: Negotiating EMU. New York, NY: Oxford University Press.

European Central Bank-ECB. 2005. "Monetary Policy and Inflation Differentials in a Heterogeneous Currency Area." Monthly Bulletin, May: 61-77.

_ 1999. "The Stability-Oriented Monetary Policy Strategy of the Eurosystem." Monthly Bulletin, January: 39-50.

Eucken, W. 1946. Uber die Verstaatlichung der Notenbank, unpublished report, Walter Eucken Archiv, Frankfurt a. M.

—. 1952. "Grundzuge der Wirtschaftspolitik." Tubingen.

Friedman, M. 1960. A Program for Monetary Stability. New York, NY: Fordam University Press.

Goodhart, C. A. E. 1998. "The Two Concepts of Money: Implications for the Analysis of Optimal Currency Areas.” European Journal of Political Economy 14: 407-32.

Hayek, F. A. 1975. Denationalization of Money. London, UK: The Institute of Economic Affairs.

Issing, O. 1999. "Hayek-Currency Competition and European Monetary Union." Speech, London, UK, May 27.

—. 2004. "On the Primacy of Price Stability." speech, Prague, 10 June.

— 2005. "One Size Fits All! A Single Monetary Policy for the Euro Area." Speech, Frankfurt a. M., May 20. http://www.ecb.int/press/key/date/2005/html/sp050520.en.html.

Johnson, P. A. 1998. The Government of Money - Monetarism in Germany and the United States. Ithaca, NY and London, UK: Cornell University Press.

Katzenstein, P. J. 1987. Policy and Politics in West Germany: The Growth of a Semisovereign State. Philadelphia, PA: Temple University Press.

Kenen, P. 1995. Economic and Monetary Union in Europe: Moving Beyond Maastricht. Cambridge, UK: Cambridge University Press. 
Keynes, J. M. 1913. Indian Currency and Finance. London, UK: Macmillan and Co.

_ 1923. A Tract on Monetary Reform. London, UK: Macmillan and Co.

_ 1930. A Treatise on Money. New York, NY: Harcourt, Brace and Company.

- 1936. The General Theory of Employment, Money and Interest. New York, NY: Harcourt, Brace.

Kolb, E. 2005. The Weimar Republic, London, UK and New York, NY: Routledge. (In German: Die Weimarer Republik, München, Oldenbourg, 1984.)

Marsh, D. 1992. The Bundesbank: The Bank That rules Europe. London, UK: Mandarin.

Parkin, B. and T. Czuczka 2010. "Merkel Seeks 'Decisive' German Cuts as Geithner Urges Spending." Bloomberg, June 6.

Sargent, T. J. and N. Wallace. 1981. "Some Unpleasant Monetarist Arithmetic." Federal Reserve Bank of Minneapolis Quarterly Review 5(3).

Tietmeyer, H. 1991. "The Role of an Independent Central Bank in Europe." In P. Downes and R. Vaez-Zadeh (Eds), The Evolving Role of Central Banks. Washington, DC: International Monetary Fund.

Vocke, W. 1973. Memoiren. Stuttgart, Deutsche Verlags-Anstalt.

Woodford, M. 2003. Interest and Prices: Foundations of a Theory of Monetary Policy. Princeton, NJ: Princeton University Press. 